\title{
An overview of the influence of some macroeconomic variables on public revenues. A panel approach for a sample of European countries.
}

\author{
Ionuț MIȘA \\ Bucharest University of Economic Studies \\ ionut.misa@yahoo.com \\ Meral KAGITCI \\ Bucharest University of Economic Studies \\ meral.kagitci@ase.ro
}

\begin{abstract}
The efficiency of the Romanian tax administration has as a main purpose the maximization of the public revenues in order to support the expenses necessary for the good functioning of the state and the achievement of the budgetary balance. Public finance policy is a priority component of the overall policy of a state, manifested in the field of distribution and encompassing all the effective methods and means of procurement and directing of financial resources and the instruments, institutions and regulations in the field in order to influence the economic processes and the existing social relations at a time in an economy.
\end{abstract}

Keywords: fiscal policy, budgetary policy, economic policy, public revenues.

\section{Introduction and literature review on budgetary policy}

An important objective of a state in order to assure its nation's wealth is to maximize the public revenues by finding new sources to be taxed or to improve the basis already existing without pressuring the contributors and maintaining them out from the area of shadow economy, following the fair rules of the fiscal policies and fiscal regulation. Also, it is preffered that these public revenues collected by the state to be used as a continuos advancement of capital, with an important contribution for the economic growth of the state.

It has been noted that public spending and taxation are frequently confused with the concept of fiscal policy, which is made up of three types of policies: policies regarding the purchase and supply of goods and services by the government, policies on taxation and policies concerned with social transfers(Case, K., Fair,R., Oster,S.,2012).

Horton, M., El-Ganaini, A. (2009) perceived fiscal policy as that kind of policy which influences the national economy through the use of public expenditures and taxes.

Regarding the type of fiscal policy, it can be said that it depends on the economic state: recession or expansion. At the state level, decision makers take different measures to stimulate or temper the economy. Sustainability of fiscal policy has an important role due to the long-term relationship between the setting of public revenues and the allocation of public funds. In this respect, each country must promote a policy which ensures that budgetary constraints are achieved (Alfonso A, 2012; Roman M, 2012, Alvarado C, 2004).

The sustainability of a nation is called into question when public revenues are too low to finance public spending and especially debt. This feature of fiscal policy does not necessarily mean maintaining a constant rate if, after a longer variation of it, its value returns to its initial form. If a fiscal policy does not lead the government to a state in which is unable to cover or monetize debt, only then it can be said that fiscal policy is indeed sustainable (Blanchard et al, 1990). 
Alfonso and Jalles (2012) analyzed the sustainability of fiscal policy, taking into account a sample of 18 countries for which annual data on debts, expenditures and revenues were collected for the period between 1970 and 2010. The main results for the whole period under review showed that the growth rate for spending, in more than half of the countries, exceeded the growth rate of revenues. The strong impact of ageing population on fiscal policy's sustainability is highlighted in countries such as Romania, Lithuania, Slovakia and the Czech Republic.

According to Văcarel. I. (2006), the two harmoniously interlinked components, the fiscal and the fiscal policy, have a role in determining the sources, the methods of sampling and the formation of the budgetary revenues, the latter being the expression of the sizing and ranking of budgetary expenditures through specific actions and instruments so financial policy is about budget revenue, and budget policy refers to budget spending.

Niță. D. (1999) noticed another differentiation between the two policies that harmoniously intertwine. Fiscal policy therefore aims to use taxes as an instrument to stimulate economic growth, while fiscal policy through state spending should aim at direct action against shocks and instability in order to ensure economic recovery.

Fiscal policy is essential to the work of international institutions, such as the International Monetary Fund (IMF) and the World Bank. Thus, the IMF aims to promote international monetary cooperation, a balanced growth of international trade, exchange rate stability and trade between countries.

In programs supported by the IMF in countries facing balance-of-payments crisis, the IMF often believes that restoring the credibility of the government's fiscal stance is essential for restoring sustainable growth. In support of low-income countries, the strengthening and reorientation of tax and spending structures often play a central role. In its technical assistance, the IMF responds to countries' requests to provide specialized advice to improve tax and spending systems. As a rule, economic growth, but not always - brings benefits to the poor; in about $90 \%$ of countries where GDP per capita has grown by at least $2 \%$ per annum over a five-year period, the poor also recorded real incomes.

In the short term, the optimum fiscal stance will vary, with countries with substantial fiscal deficits and fiscal expansion being suited to countries that have reached fiscal stability but are experiencing slowing economic growth. Expansion of the tax base can also be guaranteed in low-income countries with sound macroeconomic positions but wishing to support higher public spending as part of their poverty reduction strategies. Once the magnitude of the economic contraction in the countries affected by the Asian crisis of 1997-1999 became evident, the IMF supported a significant increase in public spending to support the economic activity of these states.

With the move towards a democratic political regime and a free market system (demand-offer), economic growth has been felt in most of the transition countries in Europe and Central Asia (EAC). Of course, this growth was accompanied by significant reforms in public finances. Moreover, government spending has fallen in line with the changing dynamics of the state, and tax revenues have begun to increase as a result of restructuring and consolidation of fiscal policies and administrations. Budget deficits have also diminished as a result of revenue growth and better spending management, and public debt rates have declined. However, even with this progress in terms of fiscal adjustment, total public spending has reached about 45\% of GDP in these EAC states, comparable to those in non-EAC countries. 


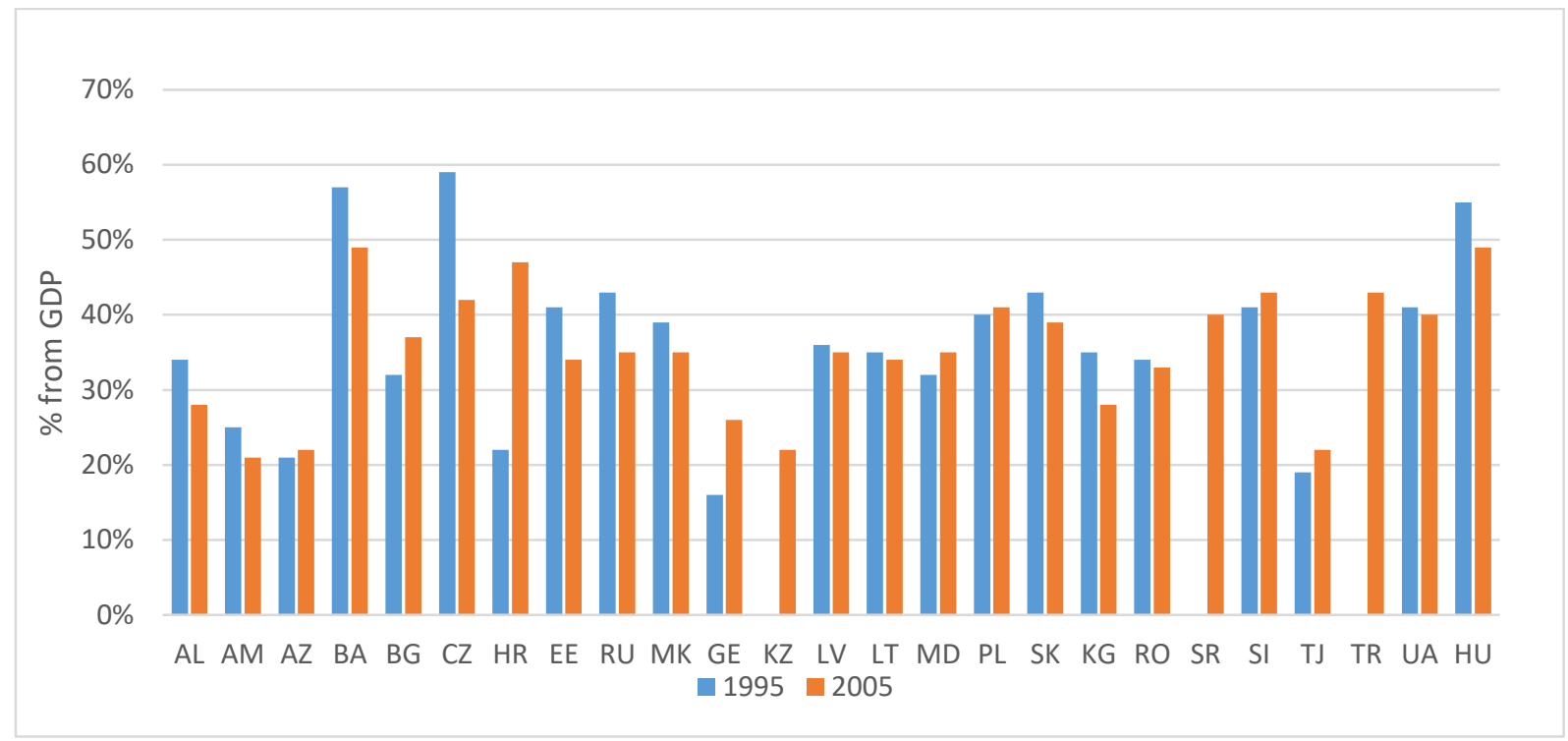

Figure 1. Total budgetary expenditure as a share of GDP over the period 1995-2005

Source: WB Report on Tax Policies and Economic Growth, 2007

As can be seen in the previous figure, for example, public expenditures for Hungary in 1995 accounted for almost 55\% of GDP, then 15 years later in 2005 it was about $49 \%$, down by $6 \%$. This is one example of many that draws attention to how spending is allocated in a public system. In view of this information, the question arises as to whether the government's size in some way diminishes economic growth, the size of government surprising how present and involved it is in public policies and the private sector. The analysis shows that the overall size of a government really influences the rate of economic growth in the EAC, but this effect depends on the state of government. In the first instance, larger governments can hinder economic growth in poorly governed countries, but this effect is nonlinear because under about one-third of GDP it has been shown that government size is not correlated with economic growth but as soon as public spending exceeds about 35\% of GDP, can have a negative impact on economic growth. Strong government mitigates this negative effect, which is why large governments do not necessarily reduce economic growth in some higher-income countries in the Organization for Economic Cooperation and Development (OECD). Many reasons have been identified that explain why large governments can hinder growth in poor governance countries. One explanation suggests that large governments are more prone to managing budget deficits during economic crises, especially when public spending is inflexible due to weak budgeting systems, resource dependency, and the public spending system that affects economic growth in at least two ways. First, some categories of activity seem to stimulate growth more than others. High levels of spending in "non-productive" areas (eg public consumption and transfers) can have a negative impact on growth, while expenditure in "productive" areas (eg investment) can promote economic growth. Secondly, within each broad category of spending, it is possible to allocate resources more or less efficiently. Here again, the state of government plays an important role. High spending in productive areas can lead to growth in prominent governments, and spending on non-productive areas may have no negative impact. Unsupported, on the other hand, economic growth in poor countries tends to be slowed down by higher levels of unproductive spending and high taxes. As a possible solution, the EAC countries will try to redirect their spending to productive areas to every possible extent, but they will not stop here. While reallocation 
of benefits brings benefits, it also depends on these countries to increase their spending efficiency in areas such as infrastructure, education, health and the pension system.

Analysis of the evolution of public revenues and the main macroeconomic indicators that can influence their size in the period 2007-2017. Case Study - Romania and a sample of 14 European states

This part of the paper intends to capture the evolution over a period of 11 (eleven) years, ie 2007-2011 - a period quite economically heterogeneous, of the public revenues and the main macroeconomic indicators that could influence their level, in 15 (fifteen) European countries, different in terms of magnitude of the main macroeconomic indicators, but in close connection with the previous Doctoral Report, in which we analyze the tax administrations within these states, wishing to conclude at the end of the doctoral thesis pertinent to how effective some of the sample is, to see comparatively where the Romanian tax administration is positioned and to make proposals to the decision makers in order to make its activity more efficient.

Table 1. The evolution of public revenues as a share of GDP over the period 2007-2017(\%).

\begin{tabular}{|l|l|l|l|l|l|l|l|l|l|l|l|l|l|l|l|}
\hline Years & HR & CZ & FI & FR & HU & IE & LV & LT & GB & PL & RO & SK & SI & ES & NL \\
\hline 2007 & 37,297 & 31,734 & 37,494 & 42,007 & 37,746 & 33,189 & 37,337 & 32,019 & 38,266 & 34,199 & 32,435 & 32,708 & 37,252 & 18,461 & 37,698 \\
\hline 2008 & 36,696 & 30,524 & 37,474 & 41,966 & 39,873 & 31,829 & 36,389 & 32,855 & 39,246 & 33,457 & 30,789 & 32,460 & 37,495 & 14,942 & 38,982 \\
\hline 2009 & 36,567 & 29,912 & 35,893 & 41,421 & 39,770 & 30,765 & 38,388 & 32,784 & 37,227 & 31,352 & 28,830 & 34,633 & 37,115 & 12,614 & 37,927 \\
\hline 2010 & 35,484 & 30,434 & 35,437 & 42,896 & 38,367 & 30,878 & 38,290 & 30,140 & 38,285 & 31,906 & 30,707 & 32,968 & 37,841 & 14,663 & 37,702 \\
\hline 2011 & 34,581 & 31,370 & 36,899 & 42,599 & 37,487 & 31,663 & 37,992 & 28,852 & 38,449 & 32,494 & 31,329 & 34,650 & 37,625 & 14,228 & 37,523 \\
\hline 2012 & 36,203 & 31,817 & 37,382 & 43,444 & 39,667 & 31,876 & 39,444 & 28,901 & 37,665 & 32,604 & 31,207 & 34,261 & 38,581 & 14,323 & 37,983 \\
\hline 2013 & 35,862 & 32,041 & 37,631 & 44,443 & 39,467 & 32,262 & 39,454 & 29,108 & 38,601 & 32,098 & 30,103 & 36,501 & 39,008 & 16,410 & 38,796 \\
\hline 2014 & 36,426 & 30,929 & 37,571 & 44,569 & 39,673 & 32,089 & 39,601 & 30,559 & 37,667 & 32,020 & 31,098 & 37,199 & 38,754 & 16,715 & 38,827 \\
\hline 2015 & 38,069 & 31,206 & 37,424 & 44,287 & 39,971 & 25,705 & 39,846 & 31,230 & 38,003 & 32,555 & 32,448 & 40,244 & 39,761 & 16,304 & 37,805 \\
\hline 2016 & 39,656 & 31,666 & 37,693 & 44,196 & 40,724 & 25,643 & 41,273 & 31,794 & 38,492 & 32,994 & 29,636 & 37,231 & 38,194 & 15,771 & 38,888 \\
\hline 2017 & 39,821 & 31,830 & 36,876 & 44,791 & 39,894 & 24,760 & 40,998 & 31,228 & 39,116 & 33,611 & 28,622 & 37,538 & 37,916 & 15,634 & 39,151 \\
\hline
\end{tabular}

The evolution of public revenues as percent from GDP for the period 2007-2017

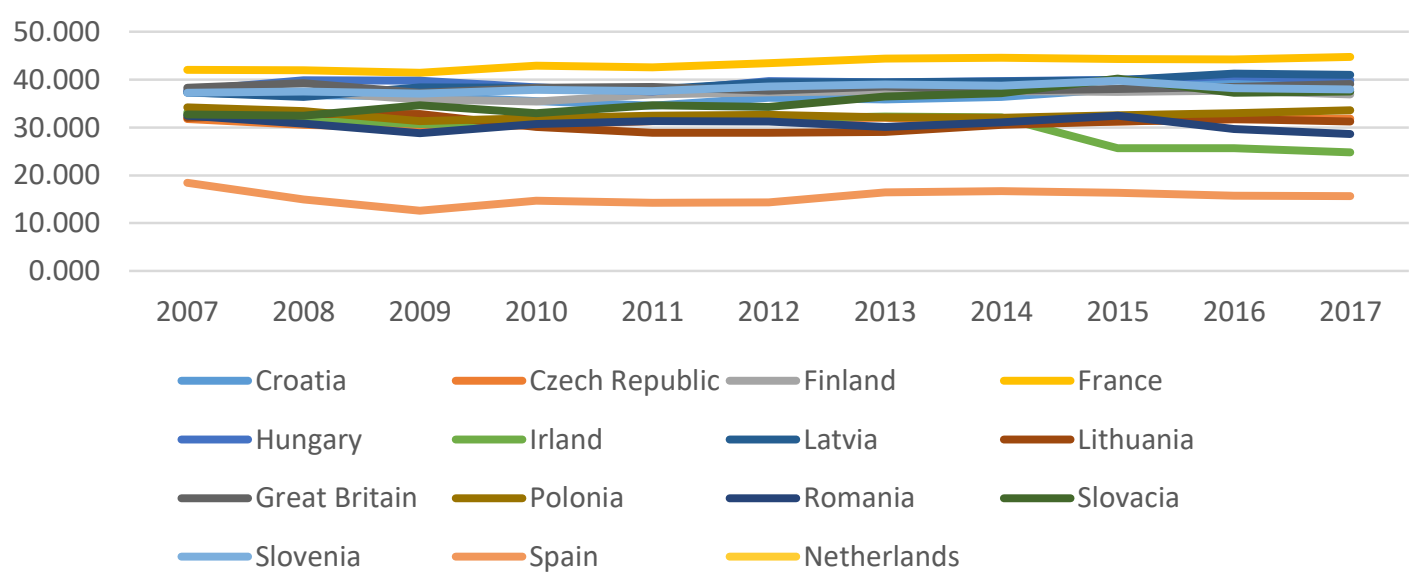

Figure 2. Evolution of public revenues as a share of GDP over the period 2007-2017 
As can be seen in Table no. 1.1 and Chart no. 1.1 where the evolution of the public revenues as a share of the GDP in the 15 European countries is surprising, there have been no significant changes within the countries during the whole analyzed period. Spain was characterized throughout the range of the smallest share of GDP revenue, for France to be characterized by the highest share of public revenue in GDP, with Romania registering higher values than Spain, but in the lower half, of the countries with the lowest share of public revenues in GDP.

Table 2. Evolution of economic growth over the period 2007-2017

\begin{tabular}{|l|r|l|l|l|l|l|l|l|r|r|r|r|r|r|r|r|}
\hline Years & HR & \multicolumn{1}{l}{ CZ } & FI & \multicolumn{1}{l|}{ FR } & HU & IE & LV & LT & GB & PL & RO & SK & \multicolumn{1}{l|}{ SI } & ES & NL \\
\hline 2007 & 5,284 & 5,603 & 5,185 & 2,361 & 0,435 & 5,209 & 9,979 & 11,087 & 2,357 & 7,035 & 6,864 & 10,800 & 6,942 & 3,769 & 3,698 \\
\hline 2008 & 2,036 & 2,682 & 0,721 & 0,195 & 0,856 & $-3,936$ & $-3,548$ & 2,628 & $-0,473$ & 4,250 & 8,260 & 5,630 & 3,300 & 1,118 & 1,699 \\
\hline 2009 & $-7,291$ & $-4,803$ & $-8,269$ & $-2,941$ & $-6,600$ & $-4,627$ & $-14,402$ & $-14,814$ & $-4,188$ & 2,820 & $-5,910$ & $-5,423$ & $-7,797$ & $-3,574$ & $-3,768$ \\
\hline 2010 & $-1,473$ & 2,273 & 2,992 & 1,966 & 0,682 & 1,885 & $-3,941$ & 1,640 & 2,183 & 3,607 & $-2,812$ & 5,042 & 1,238 & 0,014 & 2,635 \\
\hline 2011 & $-0,340$ & 1,778 & 2,571 & 2,193 & 1,658 & 3,721 & 6,381 & 6,043 & 1,645 & 5,017 & 2,007 & 2,819 & 0,649 & $-0,999$ & 1,551 \\
\hline 2012 & $-2,301$ & $-0,800$ & $-1,426$ & 0,313 & $-1,631$ & 0,183 & 4,035 & 3,827 & 1,447 & 1,608 & 2,077 & 1,657 & $-2,670$ & $-2,928$ & $-1,030$ \\
\hline 2013 & $-0,492$ & $-0,484$ & $-0,758$ & 0,576 & 2,094 & 1,337 & 2,430 & 3,499 & 2,046 & 1,392 & 3,515 & 1,491 & $-1,132$ & $-1,706$ & $-0,130$ \\
\hline 2014 & $-0,088$ & 2,715 & $-0,632$ & 0,956 & 4,225 & 8,801 & 1,858 & 3,538 & 2,948 & 3,318 & 3,411 & 2,750 & 2,979 & 1,380 & 1,423 \\
\hline 2015 & 2,401 & 5,309 & 0,501 & 1,113 & 3,536 & 25,117 & 2,972 & 2,021 & 2,349 & 3,839 & 3,872 & 4,175 & 2,259 & 3,645 & 1,959 \\
\hline 2016 & 3,536 & 2,451 & 2,772 & 1,171 & 2,281 & 4,988 & 2,064 & 2,353 & 1,789 & 3,063 & 4,801 & 3,125 & 3,148 & 3,173 & 2,192 \\
\hline 2017 & 2,921 & 4,353 & 2,653 & 2,161 & 4,137 & 7,222 & 4,636 & 4,140 & 1,823 & 4,806 & 7,260 & 3,188 & 5,001 & 2,979 & 2,869 \\
\hline
\end{tabular}

Source: Own contribution, based on data from the World Bank Note: Growth measured as relative change in GDP real 


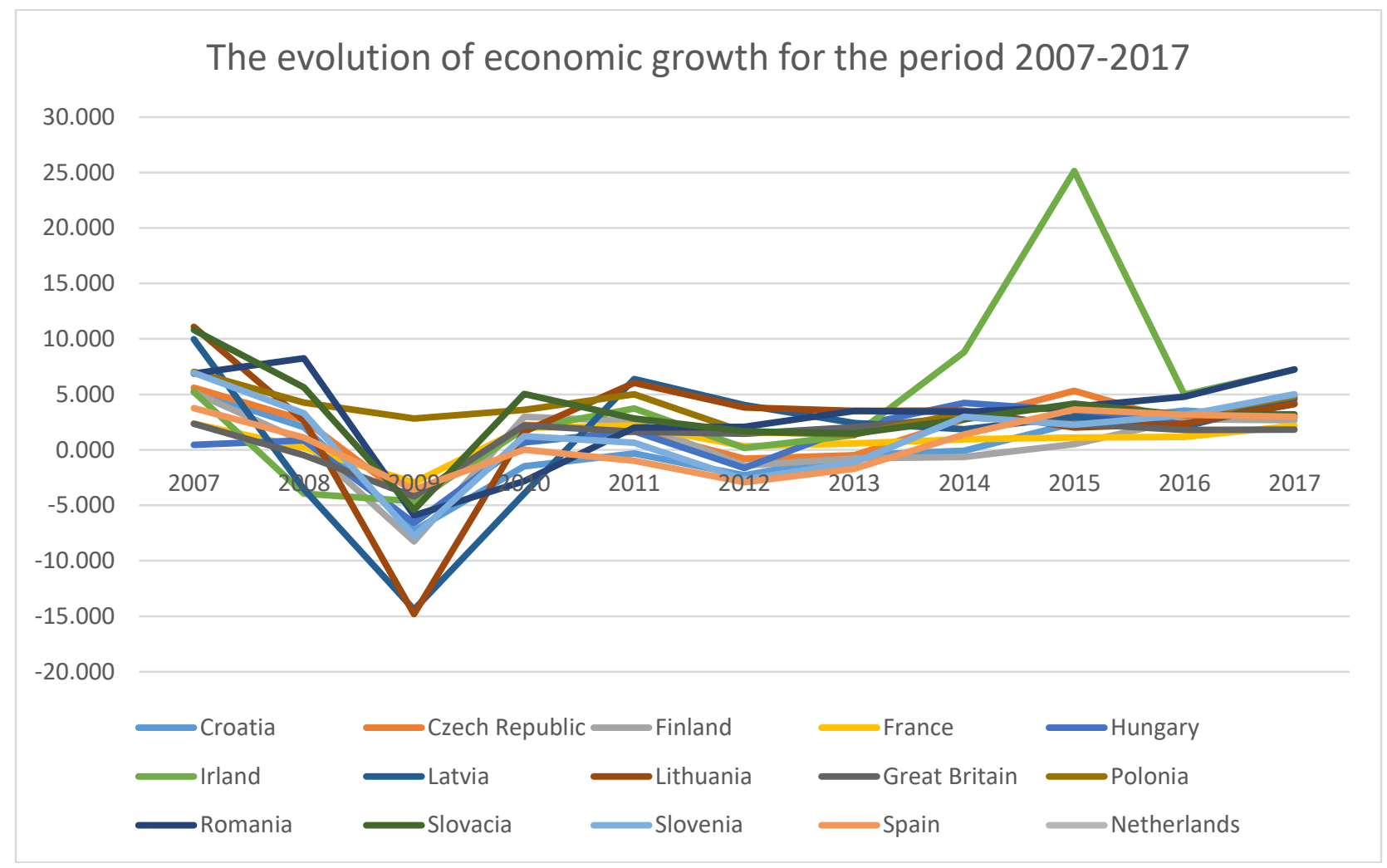

Figure 3. Evolution of economic growth over the period 2007-2017 Source: Own contribution, based on data from the World Bank

Both Table no. 2.1, and Chart no. 2 shows a heterogeneous situation regarding the economic growth recorded in the analyzed countries during the whole period, with Latvia and Lithuania showing the highest negative values of $-14.40 \%$, respectively $14.81 \%$ in the year 2009 , which can also be explained by the negative impact of the global financial crisis on the economies of these states. Ireland is the country with the highest economic growth, at $25,11 \%$ in 2015 , so that in the coming period it will see decreases in the value of this indicator. Romania recorded negative values only in the crisis years: $5.91 \%$ (2008) and 2.81\% (2009), and then, on the background of the economic recovery, the economic growth should take positive and average value over the whole period analyzed, Romania was characterized by an economic growth of 3.03\%.

From the sample of the selected countries we draw attention to Croatia, which in more than half of the analyzed period registered negative economic growth, which also led to the lowest average value over the entire range analyzed in the analyzed European states $0.38 \%$. Ireland is the European state with the highest average value over the whole time frame: $4.53 \%$. 
Table 3. The evolution of public debt as a share of GDP over the period 2007-2017(\%)

\begin{tabular}{|l|l|l|l|l|l|l|l|l|l|l|l|l|l|l|l|}
\hline Years & HR & CZ & FI & FR & HU & IE & LV & LT & GB & PL & RO & SK & SI & ES & NL \\
\hline 2007 & 37,73 & 27,47 & 33,99 & 64,54 & 65,25 & 23,91 & 7,23 & 15,87 & 41,70 & 44,16 & 12,34 & 30,10 & 22,66 & 35,51 & 43,00 \\
\hline 2008 & 39,56 & 28,25 & 32,65 & 68,78 & 71,24 & 42,40 & 16,16 & 14,57 & 49,70 & 46,30 & 13,05 & 28,46 & 21,65 & 39,40 & 54,70 \\
\hline 2009 & 48,91 & 33,56 & 41,70 & 83,04 & 77,47 & 61,55 & 32,46 & 29,01 & 63,70 & 49,43 & 22,65 & 36,29 & 34,48 & 52,70 & 56,80 \\
\hline 2010 & 58,12 & 37,36 & 47,12 & 85,26 & 80,25 & 86,00 & 40,30 & 36,22 & 75,20 & 53,13 & 30,78 & 41,20 & 38,18 & 60,07 & 59,30 \\
\hline 2011 & 64,99 & 39,83 & 48,50 & 87,83 & 80,48 & 110,88 & 37,49 & 37,18 & 80,80 & 54,10 & 34,06 & 43,68 & 46,44 & 69,46 & 61,70 \\
\hline 2012 & 70,60 & 44,47 & 53,91 & 90,60 & 78,37 & 119,93 & 36,75 & 39,77 & 84,10 & 53,72 & 37,74 & 52,17 & 53,79 & 85,74 & 66,20 \\
\hline 2013 & 81,63 & 44,91 & 56,46 & 93,41 & 77,15 & 119,82 & 35,84 & 38,76 & 85,20 & 55,69 & 39,03 & 54,74 & 70,38 & 95,45 & 67,70 \\
\hline 2014 & 85,71 & 42,17 & 60,20 & 94,89 & 76,63 & 104,27 & 38,49 & 40,54 & 87,00 & 50,25 & 40,49 & 53,52 & 80,34 & 100,37 & 67,90 \\
\hline 2015 & 85,27 & 39,96 & 63,54 & 95,58 & 76,73 & 76,93 & 34,91 & 42,59 & 87,90 & 51,12 & 39,35 & 52,34 & 82,62 & 99,44 & 64,60 \\
\hline 2016 & 82,28 & 36,81 & 62,95 & 96,59 & 75,98 & 73,56 & 37,39 & 40,11 & 87,90 & 54,16 & 38,76 & 51,82 & 78,56 & 98,99 & 61,90 \\
\hline 2017 & 77,85 & 34,67 & 61,33 & 96,80 & 73,58 & 68,56 & 36,32 & 39,73 & 87,10 & 50,62 & 36,78 & 50,86 & 73,62 & 98,36 & 57,00 \\
\hline
\end{tabular}

\section{The evolution of public debt as percent from GDP for the period 2007-2017}

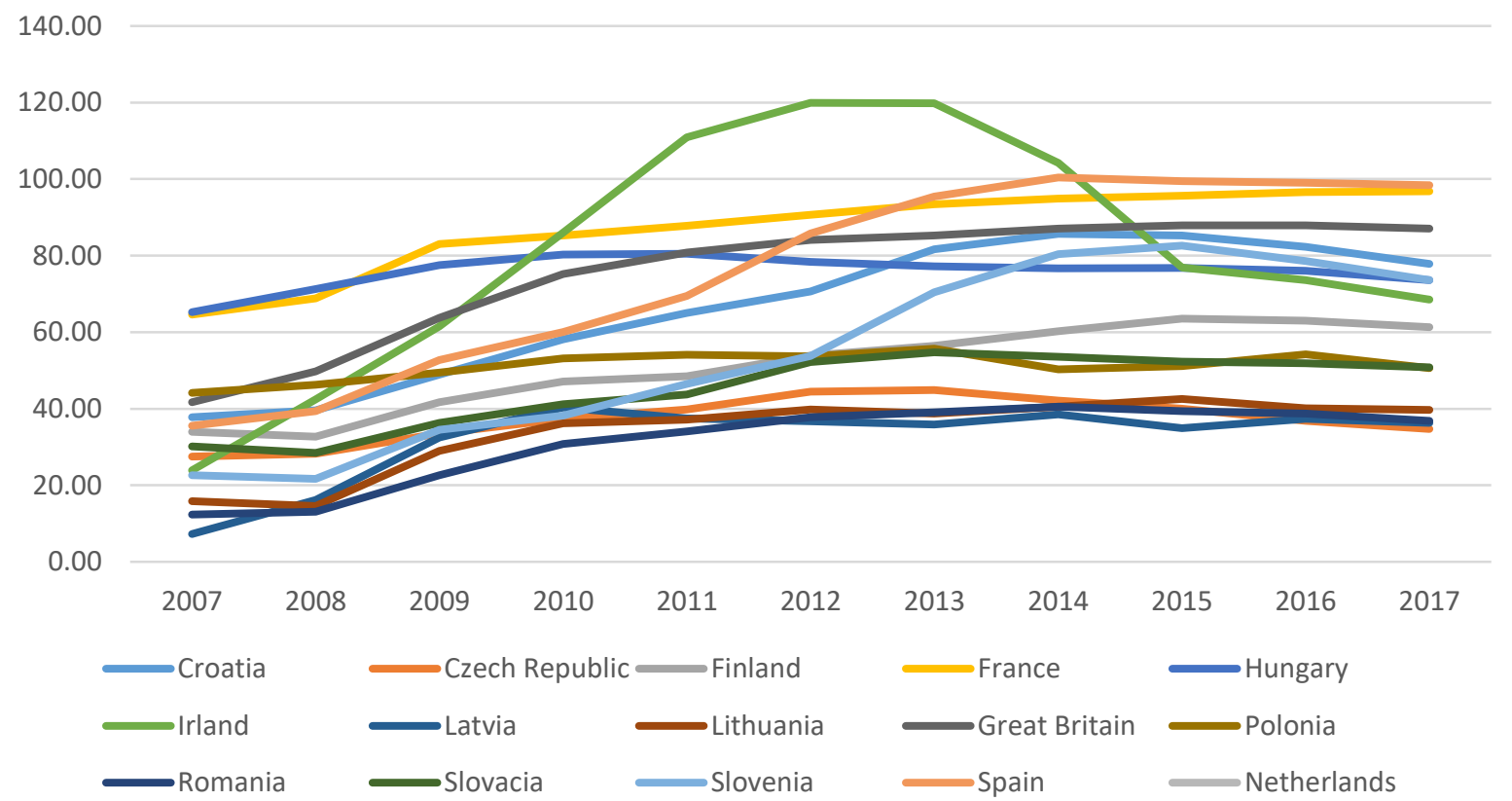

Figure 4. The evolution of public debt as a share of GDP over the period 2007-2017 Source: Own contribution, based on data available on Eurostat (AMECO)

Chart no. 2.3 and Table no. 2.3, suggestively entitled the evolution of public debt as a share of GDP over the period 2007-2017 shows that half of the countries in the sample do not meet one of the nominal convergence criteria set by the Maastricht Treaty, to exceed the $60 \%$ of GDP ratio. On average, over the whole of the analyzed period, the Netherlands has a public debt-to-GDP ratio of $60.07 \%$, slightly exceeding the level required by the European Treaty.

The European countries in the selected sample, which on average have recorded government debt values below 60\% of GDP, are: the Czech Republic (37.22\%), Finland 
(51.12\%), Latvia (32.11\% Lithuania (34,03\%), Poland (51,15\%), Romania (31,36\%), Slovakia $(45,01 \%)$ and Slovenia $(54,79 \%)$. the analysis range was $57.22 \%$. Romania recorded the lowest level of public debt considered as a share of GDP before the financial crisis, namely in 2007: 12.34\%, and in 2014 the highest value of 40.49\%. Ireland has a slightly different situation from that of other states, with an increase in 2010-2012, then the public debt as a share of GDP will follow a decreasing trend, but the significant decrease will occur between 2014 and 2015, with approximately $28 \%$.

Table 4. The evolution of public investment as a share of GDP over the period 2007-2017 (\%)

\begin{tabular}{|c|c|c|c|c|c|c|c|c|c|c|c|c|c|c|c|}
\hline ars & HR & $\mathrm{CZ}$ & $F$ & FR & HU & 115 & LV & LT & GB & PL & RO & SK & SI & ES & NL \\
\hline 007 & 5,284 & 5,603 & 5,185 & 2,361 & 0,435 & 5,209 & \begin{tabular}{|r|r|} 
& 979 \\
\end{tabular} & 11,087 & 2,357 & 7,035 & 6,864 & 10,800 & 6,942 & 3,769 & 3,698 \\
\hline 008 & 2,036 & 2,682 & 0,721 & 0,195 & 0,856 & $-3,936$ & $-3,548$ & 2,628 & $-0,473$ & 4,250 & 8,260 & 5,630 & 3,300 & 1,118 & 1,699 \\
\hline 009 & $-7,291$ & $-4,803$ & $-8,269$ & $-2,941$ & $-6,600$ & $-4,627$ & $-14,402$ & $-14,814$ & $-4,188$ & 2,820 & $-5,910$ & $-5,423$ & \begin{tabular}{|l|}
$-7,797$ \\
\end{tabular} & $-3,574$ & $-3,768$ \\
\hline 010 & $-1,473$ & 2,273 & 2,992 & 1,966 & 0,682 & 1,885 & $-3,941$ & 1,640 & 2,183 & 3,607 & $-2,812$ & 5,042 & 1,238 & 0,014 & 2,635 \\
\hline 011 & $-0,340$ & 1,778 & 2,571 & 2,193 & 1,658 & 3,721 & 6,381 & 6,043 & 1,645 & 5,017 & 2,007 & 2,819 & 0,649 & $-0,999$ & 1,551 \\
\hline 012 & $-2,301$ & $-0,800$ & $-1,426$ & 0,313 & $-1,631$ & 0,183 & 4,035 & 3,827 & 1,447 & 1,608 & 2,077 & 1,657 & $-2,670$ & $-2,928$ & $-1,030$ \\
\hline 2013 & $-0,492$ & $-0,484$ & $-0,758$ & 0,576 & 2,094 & 1,337 & 2,430 & 3,499 & 2,046 & 1,392 & 3,515 & 1,491 & $-1,132$ & $-1,706$ & $-0,130$ \\
\hline 2014 & $-0,088$ & 2,715 & $-0,632$ & 0,956 & 4,225 & 8,801 & 1,858 & 3,538 & 2,948 & 3,318 & 3,411 & 2,750 & 2,979 & 1,380 & 1,423 \\
\hline 2015 & 2,401 & 5,309 & 0,501 & 1,113 & 3,536 & 25,117 & 2,972 & 2,021 & 2,349 & 3,839 & 3,872 & 4,175 & 2,259 & 3,645 & 1,959 \\
\hline 016 & 3,536 & 2,451 & 2,772 & 1,171 & 2,281 & 4,988 & 2,064 & 2,353 & 1,789 & 3,063 & 4,801 & 3,125 & 3,148 & 3,173 & 2,192 \\
\hline 2017 & 2,921 & 4,353 & 2,653 & 2,161 & 4,137 & 7,222 & 4,636 & 4,140 & 1,823 & 4,806 & 7,260 & 3,188 & 5,001 & 2,979 & 2,869 \\
\hline
\end{tabular}

\section{An overview of public investments as percent from GDP for the period 2007-2017}

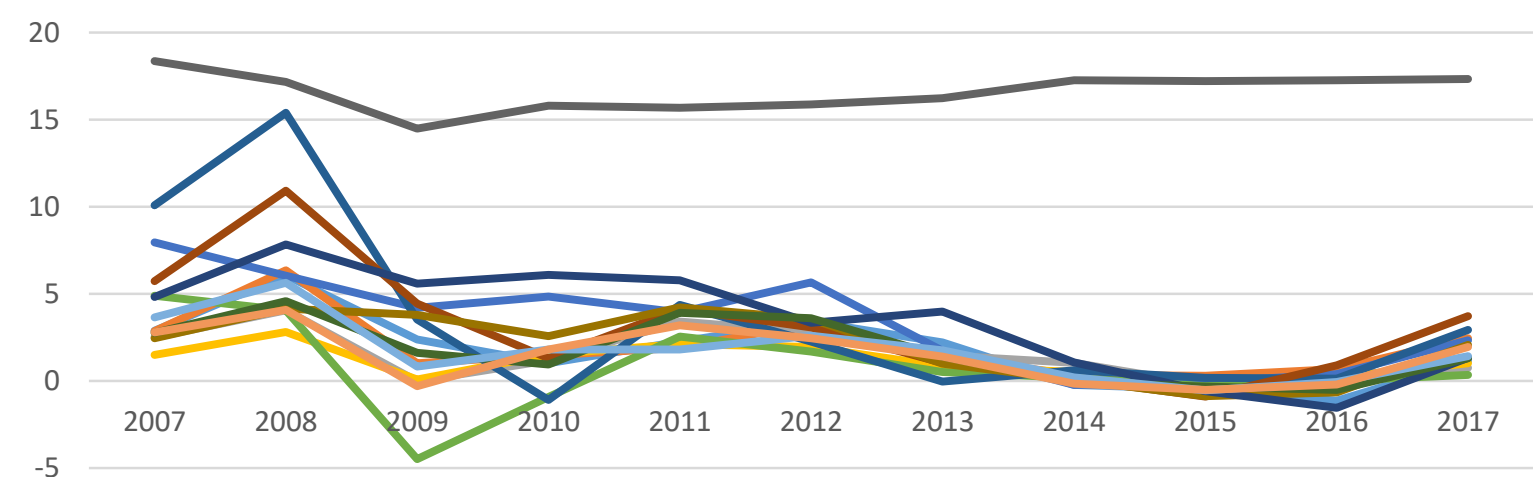

$-10$

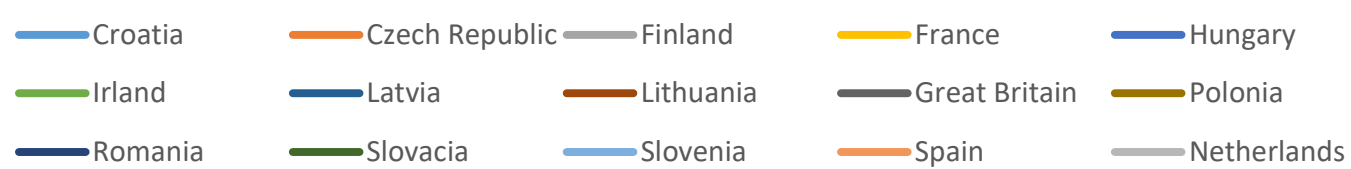

Figure 5. The evolution of public investment as a share of GDP over the period 2007-2017

Source: Own contribution based on World Bank data 
In terms of investment, considered as a change and reported in GDP, one can see how the highest value was recorded in the Netherlands in 2007, 23.35\%, and in Ireland, in 2009, the largest decrease in investments as a share of GDP of $4.47 \%$.

On average, Romania recorded $3.43 \%$ over the whole range for the share of the change in investment in GDP, knowing declines from 2014 in 2015 and from 2015 in 2016.

Table 5. The evolution of GDP per capita over the period (2007-2017)

\begin{tabular}{|c|c|c|c|c|c|c|c|c|c|c|c|c|c|c|c|}
\hline Years & HR & $\mathrm{CZ}$ & $\mathrm{Fl}$ & FR & HU & IE & LV & LT & $G B$ & $\mathrm{PL}$ & RO & SK & SI & ES & NL \\
\hline 2007 & 615,8202 & 41814,82 & 4078,823 & 47024,23 & 3288,987 & \begin{tabular}{|l|l|}
4857,368 \\
\end{tabular} & 36402,56 & 106018,5 & 2635,351 & 1108,997 & 9101,257 & 23841,32 & 53324,38 & 16586,41 & 85170,86 \\
\hline 2008 & 674,7564 & 45699,2 & 4177,658 & 49773,17 & 3908,237 & 5574,41 & 40667,88 & 114293,8 & 3324,728 & 1359,087 & 11635,27 & 27501,81 & 55746,84 & 18094,55 & 97007,94 \\
\hline 2009 & 668,2976 & 41732,71 & 3369,408 & 46521,5 & 3755,001 & 5619,118 & 40881,38 & 103198,7 & 2822,66 & 1192,652 & 8562,814 & 24633,8 & 46207,06 & 14726,32 & 80067,18 \\
\hline 2010 & 662,2795 & \begin{tabular}{|l|}
41785,56 \\
\end{tabular} & 3651,967 & 47397,9 & 4515,998 & 6531,927 & 52374,79 & 104965,3 & 3073,534 & 1369,146 & 10675 & 23437,47 & 52132,92 & 14638,6 & 87770,27 \\
\hline 2011 & 740,9358 & 46810,33 & 4353,121 & 50789,05 & 5283,225 & \begin{tabular}{|l}
7729,343 \\
\end{tabular} & 66813,35 & 115761,5 & 3842,632 & 1556,208 & 14351,21 & 24985,25 & 59666,07 & 17454,84 & 100711,2 \\
\hline 2012 & 766,8438 & 44065,25 & 4546,739 & 48421,8 & 5561,26 & 7832,903 & 76496,37 & 106749 & 4249, 667 & 1666,736 & 15434,57 & 22532,44 & 57197,2 & 17421,89 & 101668,2 \\
\hline 2013 & 810,2656 & 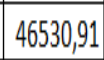 & 4763,069 & 53612,83 & 5820,819 & 6036,192 & |89524,84 & 113625,1 & 4341,444 & 1772,865 & 16007,09 & 23357,94 & 60347,69 & 19072,24 & 103059,2 \\
\hline 2014 & 830,1139 & 48142,83 & 5061,398 & 57543,67 & 5954,495 & 5540,984 & 94004,39 & 118823,6 & 4438,685 & 1842,74 & 14125,91 & 24202,43 & 59241,61 & 20247,2 & 97199,92 \\
\hline 2015 & 814,5464 & 41394,66 & 4889,461 & 50581,97 & 5566,558 & 4862,3 & \begin{tabular}{|l|l|}
75484,29 \\
\end{tabular} & 100428,4 & 3756,379 & 1575,346 & 9314,545 & \begin{tabular}{|l|}
20873,16 \\
\end{tabular} & 50832,55 & 17412,45 & 74521,57 \\
\hline 2016 & 734,8026 & 42443,47 & 5197,509 & 54802,17 & 5545,26 & 5219,109 & \begin{tabular}{|l|}
74017,18 \\
\end{tabular} & 101305,5 & 3857,276 & 1390,382 & 8744,964 & 21650,21 & 51617,54 & 18228,06 & 70941,53 \\
\hline 2017 & 765,6839 & 44665,51 & 5589,389 & 55672,95 & 6053,867 & 5593,854 & 80892,82 & 104498,7 & 4045,419 & 1433,813 & 10749,06 & 23601,4 & 53253,48 & 20200,38 & 75704,25 \\
\hline
\end{tabular}

\section{The evolution of GDP per capita over the period 2007-2017}

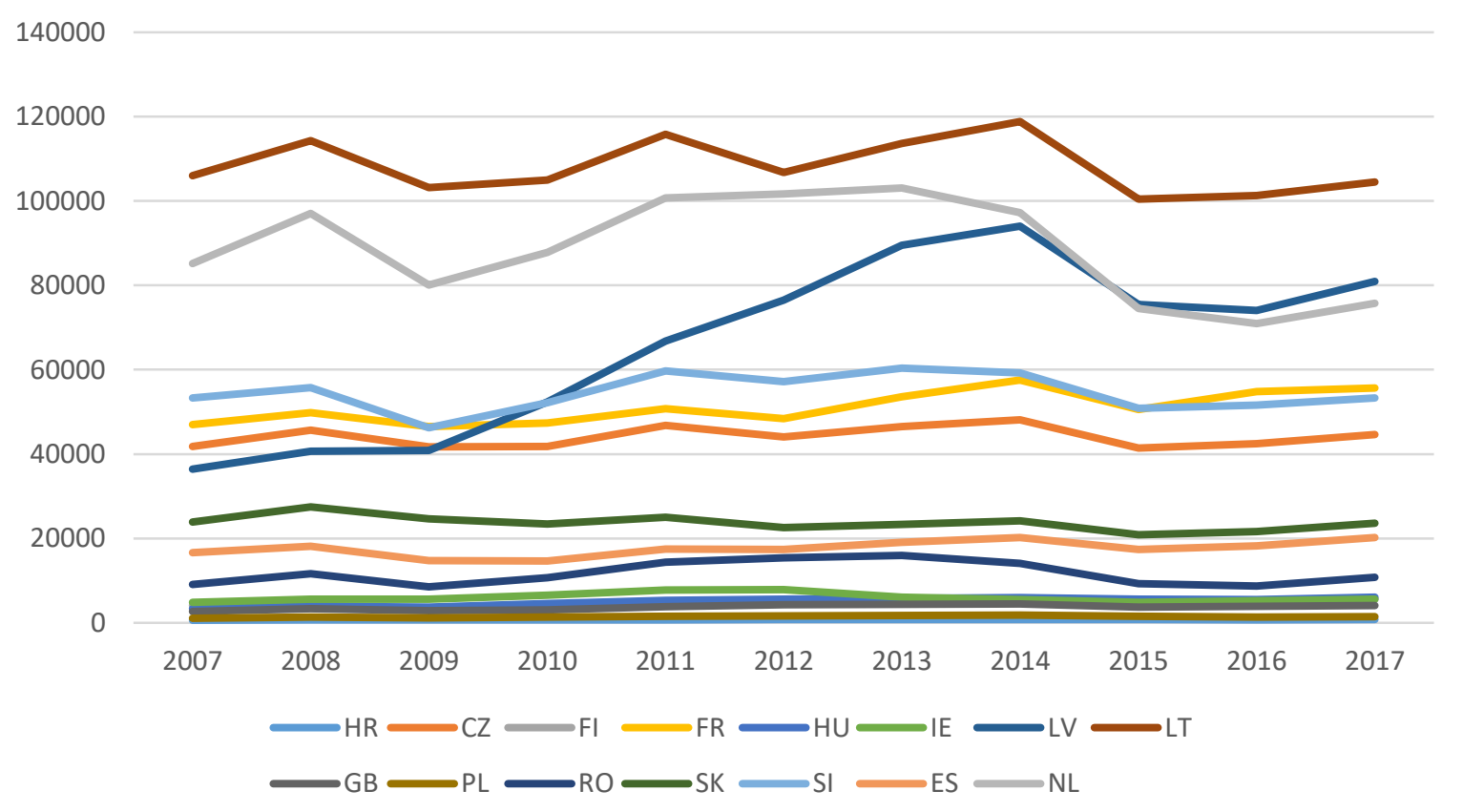

Figure 6. The evolution of GDP per capita over the period (2007-2017)

Source: Own contribution based on World Bank 
As regards gross domestic product per capita, it is noted that the highest value is registered in Lithuania in 2014, which is worth USD 118823.6 per capita. The lowest value was recorded by Croatia in 2007, reaching only USD 615.8202 per capita.

Romania recorded an average of 10750 USD per capita in the analyzed period, the maximum being in 2013 and the lowest in 2009 due to post-crisis consequences.

\section{Methodology}

Panel or pool data involves observations that have both cross-sectional identifiers and their time course. Analysis of this data type is done in Eviews in panel work files.

The basic class of models that can be estimated using panel data tools can be written as follows:

$Y=\alpha+X \beta+\delta+\gamma+\varepsilon$

Where: Yit is the dependent variable, Xit is a dimensional vector of $\mathrm{k}$ regressions, and $\varepsilon$ are the innovations for the $\mathrm{M}$ and transverse units observed for $\mathrm{T}$ periods. The terms $\delta$ i and $t \gamma$ represent the specific (random or fixed) effects for cross-section units or for certain time periods. The presence of specific transverse or temporal effects can be captured and analyzed using fixed effects and random effects techniques. Patterns can be specified that contain effects in either or both dimensions, for example, a fixed effect in cross-section size, a random effect in the size of the period, or a fixed effect in the crosssection, and a random effect in the size of the period. It should be pointed out that, however, those with random effects in both dimensions can be estimated only when the panel is balanced, so that each cross section has the same set of temporal observations. Fixed-effect specifications are treated using a simple approach that consists in eliminating the mean of the transverse or temporal dependent variable and then using a regression equation using the resulting data. Specifications with random effects assume that the corresponding effects $\delta \mathrm{i}$ and $\mathrm{t} \gamma$ are realizations of independent random variables with zero mean and finite variance.

Most importantly, the random-based specification implies that the specific effect is uncorrelated with the innovations of the equation. Eviews processes models with random effects using FGLS techniques.

Eviews allow the estimation of panel equations using the OLS method or the instrument variable method, with fixes for fixed or random effects in both cross-sectional and temporal cross-section sizes, AR errors and robust standard errors.

Eviews automatically estimates the appropriate fixed-based specifications, calculates the test statistics, and displays the results and auxiliary equations. Increasing interest in panel data and increasing availability has led to the expansion of various statistical tests for panel data. Recent specialty literature has focused a lot on cointegration tests in the panel and thus, Eviews can compute several types of cointegration tests in panel data.

The variables used in the model are:

$\checkmark$ REVENUES;

$\checkmark$ GDP_CAPITA;

$\checkmark$ INVESTMENT;

$\checkmark$ INFLATION;

$\checkmark$ UMENPLOYMENT.

The analysis of the impact of macroeconomic indicators on the budget revenues of recipient countries is based on the estimation of a regression on panel data. The data is specified as a cross-section unit panel - country and unit of time - year (2007, $2009, \ldots . ., 2017)$. 
Therefore, the panel data model to be estimated has the following form:

REVENUES_GDP $=\alpha 1 * G D P C+\alpha 2 * T I_{-} G D P *+\alpha 3 * I N F L A T I O N+\alpha 4 *$ UNEMPLOYMENT

$+\varepsilon$.

$\alpha \mathrm{k}=$ coefficients in the equation to be determined, $\mathrm{k}=1,2,3, \ldots, 9$.

$\varepsilon=$ residual variable

\section{Econometric model on the influence of some macroeconomic variables on public revenues}

The econometric model seeks to capture the influence of macroeconomic variables such as GDP per capita, total investment, inflation and unemployment rates on public revenues as a major objective of a state's finances, which is achievable through tax administrations.

First, we need to study the stationarity of the data series. To avoid a spurious regression, all the variables used must be stationary. For reasons of robustness, we will use three different tests with two specifications each. All tests have as a null hypothesis the existence of a unit root. This is due to the fact that the series is non-stationary. We reject the null hypothesis and accept the alternative in situations where the probability of the test is below (0.1).

Table 6. Panel Unit Root Tests Results

\begin{tabular}{|c|c|c|c|c|c|c|}
\hline \multirow[t]{3}{*}{ Variables } & \multicolumn{6}{|l|}{ Method } \\
\hline & \multicolumn{2}{|l|}{ LLC } & \multicolumn{2}{|l|}{ IPS } & \multicolumn{2}{|l|}{$\mathrm{ADF}$} \\
\hline & Intercept & Trend & Intercept & Trend & Intercept & Trend \\
\hline Public Revenues & $\begin{array}{l}-5.8882 \\
(0.0000)\end{array}$ & $\begin{array}{l}-3.3284 \\
(0.0004)\end{array}$ & $\begin{array}{l}-1.6830 \\
(0.0462)\end{array}$ & $\begin{array}{l}-1.2213 \\
(0.1110)\end{array}$ & $\begin{array}{c}-1.77631 \\
(0.0378)\end{array}$ & $\begin{array}{l}-2.04749 \\
(0.0203)\end{array}$ \\
\hline GDP per capita & $\begin{array}{l}-8.6494 \\
(0.0000)\end{array}$ & $\begin{array}{l}-28.912 \\
(0.0000)\end{array}$ & $\begin{array}{l}-4.5444 \\
(0.0000)\end{array}$ & $\begin{array}{l}-8.86833 \\
(0.0000)\end{array}$ & $\begin{array}{l}-4.67999 \\
(0.0000)\end{array}$ & $\begin{array}{l}-8.70740 \\
(0.0000)\end{array}$ \\
\hline Investment & $\begin{array}{l}-11.0153 \\
(0.0000)\end{array}$ & $\begin{array}{l}-12.1536 \\
(0.0000)\end{array}$ & $\begin{array}{l}-5.04984 \\
(0.0000)\end{array}$ & $\begin{array}{l}-2.1611 \\
(0.0000)\end{array}$ & $\begin{array}{l}-4.82634 \\
(0.0000)\end{array}$ & $\begin{array}{c}-3.20851 \\
(0.0000)\end{array}$ \\
\hline Inflation (TI_GDP) & $\begin{array}{l}-11.0395 \\
(0.0000)\end{array}$ & $\begin{array}{l}-8.5495 \\
(0.0000)\end{array}$ & $\begin{array}{l}-4.9852 \\
(0.0000)\end{array}$ & $\begin{array}{l}-8.5495 \\
(0.1000)\end{array}$ & $\begin{array}{l}-4.7397 \\
(0.0000)\end{array}$ & $\begin{array}{l}-2.2490 \\
(0.0123)\end{array}$ \\
\hline Unemployment & $\begin{array}{l}-4.9244 \\
(0.0000)\end{array}$ & $\begin{array}{l}-14.6627 \\
(0.0000)\end{array}$ & $\begin{array}{l}-1.9368 \\
(0.0264)\end{array}$ & $\begin{array}{l}-2.76269 \\
(0.0029)\end{array}$ & $\begin{array}{l}-2.2990 \\
(0.0108)\end{array}$ & $\begin{array}{l}-1.3532 \\
(0.0880)\end{array}$ \\
\hline
\end{tabular}

Note: The null hypothesis is that the series is a unit-root process; $p$-values are reported in parenthesis.

So the conclusion is that, in addition to Public Revenues at IPS-Trend, all variables have a stationary behavior. So they can be used without the risk of a false regression. The next step is to apply the Hausman test to determine what types of effects should be included in the panel model. First, we need to see what fixed effects, random effects and no effects are.

This tests whether cross-sectional effects are indicated at the expense of fixed effects. So the null hypothesis is that the variable effects are those indicated for countries. It can be noticed that the probability of error when rejecting the null hypothesis is quite high (0.2445), therefore above the maximum accepted threshold of (0.1), and we will select the fixed effects for the countries in the sample (cross-section). The same can not 
be said about the Year (Period). In this case we can not reject the null hypothesis, so we will use variable effects for the years in the sample. The results are presented below:

Tabel 7. Hausman Test Results

\begin{tabular}{|llll|}
\hline Test Summary & Chi-Sq. Statistic & Chi-Sq. d.f. & Prob. \\
Cross-section random & 5.446514 & 4 & 0.2445 \\
Period random & 8.020941 & 4 & 0.0908 \\
\hline
\end{tabular}

The Hausman test detects endogenous regressions (predictor variables) in a regression model. Endogenous variables have values that are determined by other variables in the system. Having endogenous regressions in a model, ordinary least squares estimators will fail because one of the OLS assumptions is that there is no correlation between the predictor variable and the error term. Estimators of instrumental variables can be used as an alternative in this case. However, before deciding on the best regression method, you first need to know if predictor variables are endogenous.

Interpreting the result from a Hausman test is that if $\mathrm{p}$ is small (less than 0.05), then the null hypothesis is rejected. In our case, this probability is greater than $5 \%$, so the null hypothesis will be accepted.

Table 8. Summarizes the results of the estimates.

Fixed effects OLS (Cross Section fixed effects + Period random)

Dependent Variable: REVENUES_GDP

Method: Panel Least Squares

Date: 06/19/19 Time: 10:02

Sample (adjusted): 20082017

Periods included: 10

Cross-sections included: 15

Total panel (balanced) observations: 150

\begin{tabular}{lrrrr}
\hline \hline Variable & Coefficient & Std. Error & t-Statistic & Prob. \\
\hline \hline C & -0.409596 & 5.992546 & -0.068351 & 0.9456 \\
REVENUES_GDP(-1) & 0.614200 & 0.070549 & 8.706060 & 0.0000 \\
GDPC(-1) & 1.335189 & 0.618490 & 2.158790 & 0.0327 \\
TI_GDP(-1) & 0.180916 & 0.127078 & 1.423657 & 0.0969 \\
INFLATION(-1) & -0.186682 & 0.126324 & -1.477805 & 0.1419 \\
UNEMPLOYMENT(-1) & 0.056365 & 0.037276 & 1.512083 & 0.1329 \\
\hline \hline & Effects Specification & & \\
\hline \hline & & & \\
Cross-section fixed (dummy variables) & & 34.43502 \\
\hline \hline R-squared & \multirow{2}{*}{0.976053} & Mean dependent var & 6.622627 \\
Adjusted R-squared & 0.972553 & S.D. dependent var & 3.146947 \\
S.E. of regression & 1.097190 & Akaike info criterion & 3.548365 \\
Sum squared resid & 156.4972 & Schwarz criterion & 3.310030 \\
Log likelihood & -216.0210 & Hannan-Quinn criter. & 2.020713 \\
F-statistic & 278.8709 & Durbin-Watson stat & \\
Prob(F-statistic) & 0.000000 & & \\
\hline \hline
\end{tabular}




\begin{tabular}{|lllll|}
\hline Variables & Coefficient & Std. Error & t-Statistic & Prob. \\
\hline Intercept & $-0,409596$ & 5,992546 & $-0,068351$ & 0.9456 \\
GDP per capita & 1,335189 & 0,618490 & 2,158790 & 0,0327 \\
Investment & 0,180916 & 0,127078 & 1,423657 & 0,0969 \\
Inflation & $-0,186682$ & 0,126324 & $-1,477805$ & 0,1419 \\
Unemployment & 0,056365 & 0,037276 & 1,512083 & 0,1329 \\
\hline R-squared & 0.976053 & & & \\
F-statistic & 278,8709 & & & \\
Prob(F-statistic) & $(0.0000)$ & & & \\
\hline
\end{tabular}

Our equation of regression is :

REVENUES_GDP $=0,6142 *$ REVENUES_GDP(-1)+1,335189*GDPC(-1)+0,180916*TI_GDP(1)-0,186682*INFLATION(-1)+0,056365*UNEMPLOYMENT(-1)-0,409596

Based on the above results, we have obtained the following conclusions, namely that, with an increase in the GDP per capita rate, it will lead to a decrease in the budget revenues by 1,335189 percentage points.

Also, a change with a percentage point of investment will result in a 0.180916 percentage point change in budget revenue.

Similarly, the inflation rate have a negative impact, as with a percentage, budget revenues will fall by 0,186682 and unemployment have a positive impact and it causes an increase by 0,056365 percentage points.

\section{Conclusions and recommendations}

This paper analyzes the dependence of macroeconomic factors on budget revenues. The analysis was based on a flat-panel model with fixed effects. The Hausman test was used to select the appropriate model. The study shows that the factors under consideration have a negative impact on budget revenues. The errors that affected these data come from the fact that the period under review is relatively small and does not show the impact of these long-term factors, this being the biggest drawback of this study. Unfortunately, we can not choose a longer time because of the lack of data in the analyzed countries. At the same time, between the analyzed years, ie 2007-2017, is included the period of global economic and financial crisis, which affects to a certain extent the fairness of evaluations by disturbances of different intensities from one economic indicator to another, which it produces.

Again, it can be observed that the analyzed economic indicators are in close correlation with the budget revenues, with the mention that this correlation is valid in practice when we have a modern tax administration.

\section{References:}

Afonso, A., Jalles, J.T., (2012), Revisiting Fiscal Sustainability. Panel Cointegration and Structural Breaks in OECD Countries., Working Paper Series, No. 1465, August. European Central Bank

Alvarado, C., Izquierdo A., Panizza U., (2004), Fiscal Sustainability in Emerging Market Countries with an Application to Ecuador, Working Paper No. 511, InterAmerican Development Bank

Barna, F., Mura, O., (2011), Fiscal-Budget Policy Sustainability in Romania (2003-2009), Economic Sciences Series, Vol. 63, No. 1, pp. 65-72 
Barro, R.J., (1990), Government Spending in a Simple Model of Endogenous Growth, Journal of Political Economy, 98, 5, pp.103-125

Barro, R., Sala-i-Martin, X., (1992), Public Finance in Models of Economic Growth, Review of Economic Studies, 1992, Vol. 59, Issue 4, pp. 645-661

Barna, F., Mura, O., (201), Fiscal-Budget Policy Sustainability in Romania (2003-2009), Economic Sciences Series, Vol. 63, No. 1, pp. 65-72.

Blanchard, O., Chouraqui, J., Hagemann, R., Sartor, N., (1990), The sustainability of fiscal policy: new answers to an old question., OECD Economic Studies, No. 15, Autumn, pp. 7- 36

Brașoveanu, L.O., Brașoveanu, I., (2008), The Correlation between fiscal policy and economic growth, Theoretical and Applied Economics, Asociația Generală a Economiștilor din România - AGER, 7(524), pp.19-26

Burgess, R., Stern, N., (1993), Taxation and Development., Journal of Economic Literature, Vol. XXXI, June 1993, pp. 762-830, London School of Economics

Canagarajab, S., Brownbridge, M., Paliu, A., Dumitru, I., (2012), The Challenges to Long Run Fiscal Sustainability in Romania, Policy Research Working Paper, No. 5927

Case, K., Fair, R., Oster, S., (2012), Principles of Macroeconomics, Prentice Hall, p. 165

Chamley, C., (1986), Optimal Taxation of Capital Income in General Equilibrium with Infinite Lives, Econometrica, Vol. 54, May, pp. 607-622

Dima, B., Lobont, O., Nicolescu, C., (2009), The fiscal revenues and public expenditures: Is their evolution sustainable? The Romanian case, Annales Universitatis Apulensis Series Oeconomica, Vol. 11, No. 1, pp. 416-425

Djelloul, D., Rouaski, K., Toumache, R.Talbi, B., (2014), The impact of fiscal policy on economic growth: Empirical evidence from panel estimation.The 2014 WEI International Academic Conference Proceedings,. New Orleans: The West East Institute, pp. 1-8

Dornean, A., Oanea, D.-C., (2015), Romanian fiscal policy sustainability during financial crisis: a cointegration approach, Procedia Economics and Finance 20(2015), pp. 163-170

Georgescu, F., (2017), „Macrostabilitatea, creșterea economică și dezvoltarea, Conferința Measuring Development in Turbulent Times, SNSPA, București

Helms, L.J., (1985), The Effect of State and Local Taxes on Economic Growth: A Time Series-Cross Section Approach, The Review of Economics and Statistics, Vol. 67, Issue 4, pp. 574-582

Hoppner, F., (2003), Business Cycle Effects of Fiscal Policy, Empirical Evidence from Germany

Horton, M., El-Ganaini, A., (2009), Back to Basics: What Is Fiscal Policy?, finance and Development, 2009, FMI, available online at https://www.imf.org/external/pubs/ft/fandd/2009/06/pdf/basics.pdf

Judd, K., (1985), Redistributive Taxation in a Simple Perfect Foresight Model, Journal of Public Economics 28 (1985), North Holland, pp. 59-83

Kuncoro, H., (2011), The Indonesia's State Budget Sustainability and Its Implication for Financial System Stability, Romanian Journal of Fiscal Policy, Vol. 2, No. 1, pp. 3653

Mendoza, E.G., Milesi-Ferretti, G.M., Asea, P., (1997), On the ineffectiveness of tax policy in altering long-run growth: Harberger's superneutrality conjecture, Journal of Public Economics 66(1997), pp. 99-126

Myles, G.D., (2000), Taxation and Economic Growth, Fiscal Studies (2000), Vol. 21, No. 1, pp.141-168 
Niță, D., (coordonator), (1999), Dicționar de economie, Editura Economică, p.345, p. 356

Roman, M. D., Roman, M., Talvan, M., (2012), A Macroeconometrical Model of Sustainable Fiscal Policy Study Case on Romania, International Journal of Trade Economics and Finance, Vol. 3, No. 1, pp. 73-77.

Romer, C., Romer, D., (2010), The Macroeconomic Effects of tax Changes: Estimates Based on a new Measure of Fiscal Shocks , American Economic Review, No. 100, pp. 763-801

Romer, D., (2012), Advanced Macroeconomics (4th ed.), New York: McGraw Hill Companies

Sava, A. S., (2011), Romanian Public Expenditures Policy during the Economic Crisis, The Annals of "Dunărea de Jos", University of Galați, Fascicle I, Economics and Applied Informatics, No 1

Toledo, J.A., Venieris, Y.P., (2014), Fiscal policy, growth, income distribution and sociopolitical instability, European Journal of Political Economy, No. 34(2014), pp. 315-331

Văcărel, I.(coordonator), (2006), Finanțe Publice, Editura Didactică și Pedagogică, pp. 108-126, p. 645

World Bank Report, (2007), Fiscal Policy and Economic Growth, the World Bank, Lessons for Eastern Europe and Central Asia, Chery Gray, Tracey Lane, Aristomene Varoudakis

Zaidi, A. and Rejniak, M., (2010), Fiscal Policy and Sustainability in View of Crisis and Population Ageing in Central and Eastern European Countries, Policy Brief, August, European Centre for Social Welfare Policy and Research, Vienna http://www.bnro.ro/PublicationDocuments.aspx?icid=6851.

*** EUROSTAT website,

http://ec.europa.eu/economy_finance/ameco/user/serie/SelectSerie.cfm

***World Bank's website, https://data.worldbank.org/

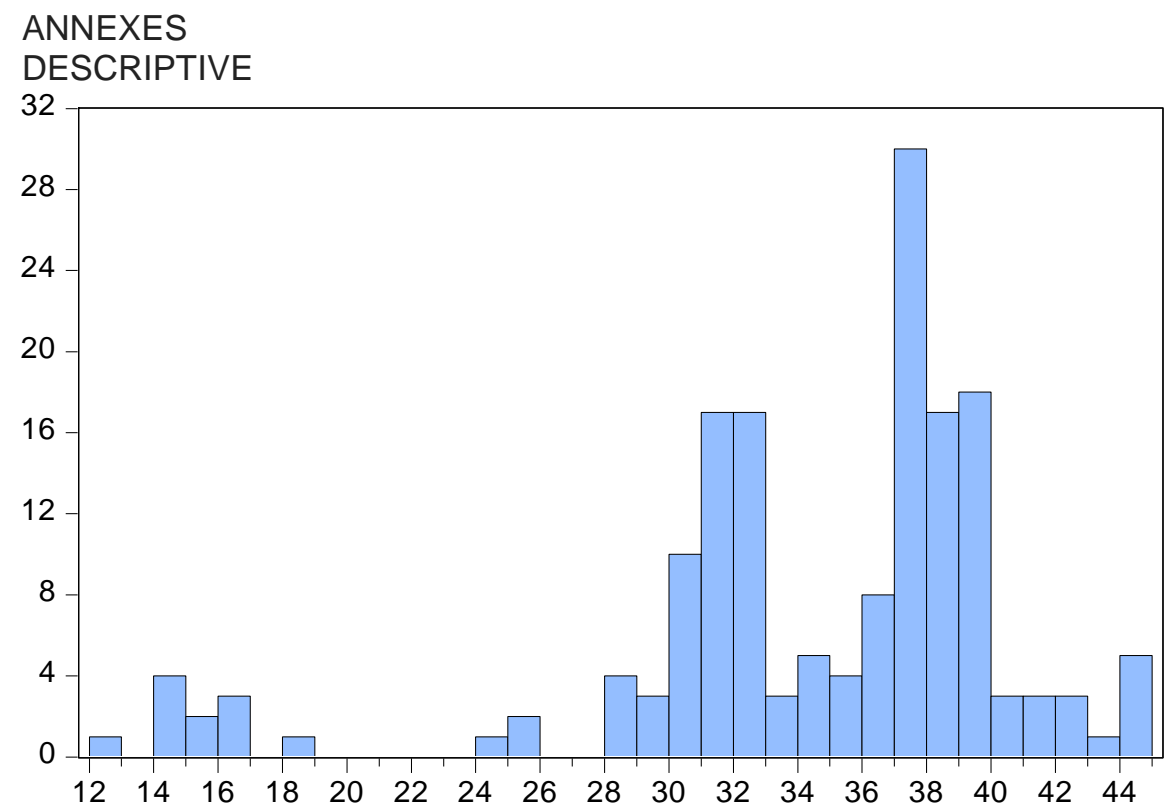

STATISTICS

Series: REVENUES

Sample 20072017

Observations 165

Mean

34.45511

Median

36.69607

Maximum

44.79137

Minimum

12.61431

Std. Dev. $\quad 6.504856$

Skewness $\quad-1.502020$

Kurtosis

5.539101

Jarque-Bera 106.3651

Probability

0.000000 

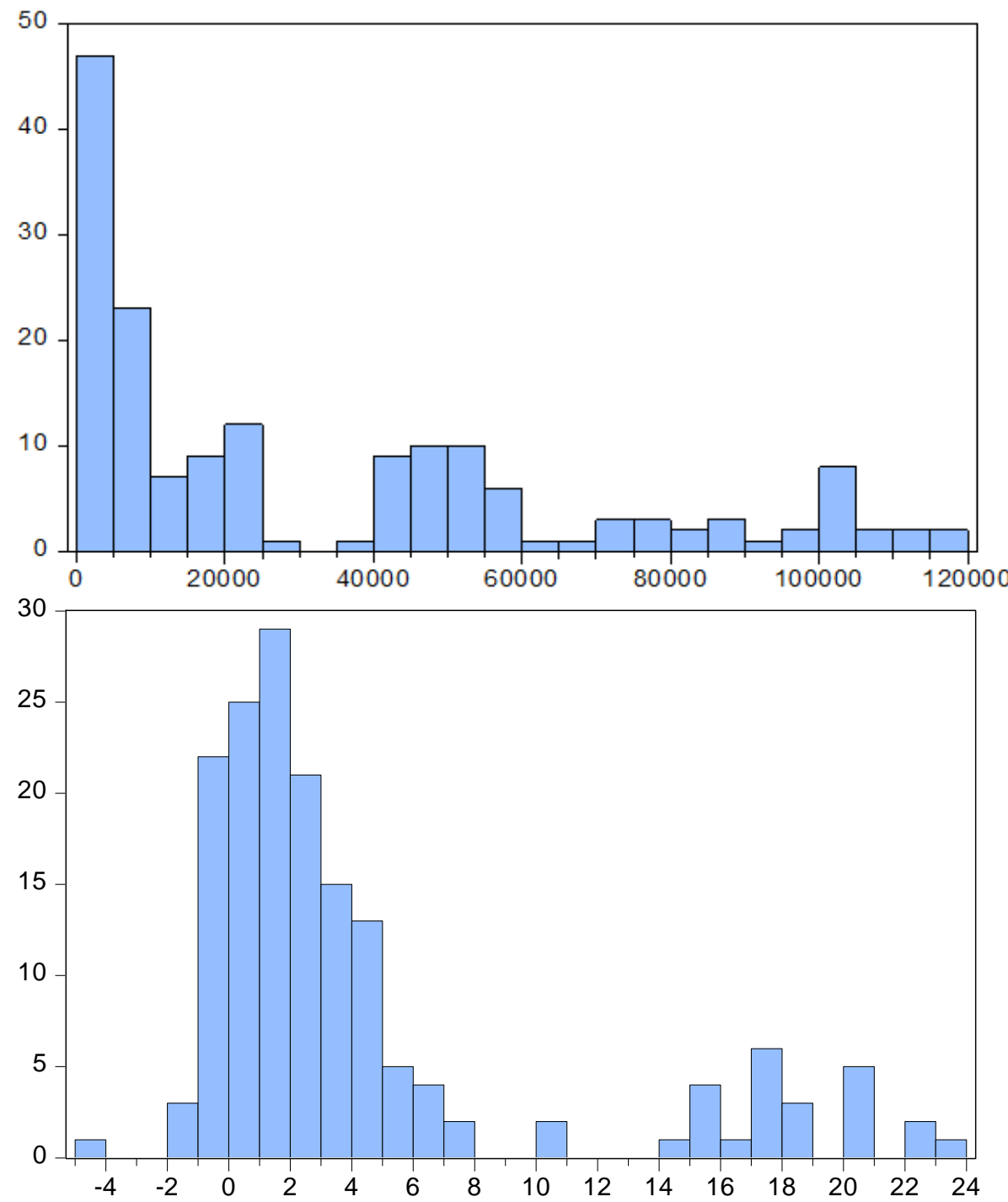

Series: GDP_CAPITA

Sample 20072017

Observations 165

Mean

32462.52

Median

17454.84

Maximum $\quad 118823.6$

Minimum $\quad 615.8202$

Std. Dev. $\quad 34095.47$

Skewness $\quad 0.975564$

Kurtosis $\quad 2.760131$

Jarque-Bera $\quad 26.56801$

Probability $\quad 0.000002$

Series: INVESTMENTS

Sample 20072017

Observations 165

Mean

4.323414

Median

2.216582

Maximum

23.35000

Minimum

$-4.478103$

Std. Dev.

6.142559

Skewness

1.713288

Kurtosis

4.772015

Jarque-Bera 102.3101

Probability $\quad 0.000000$ 


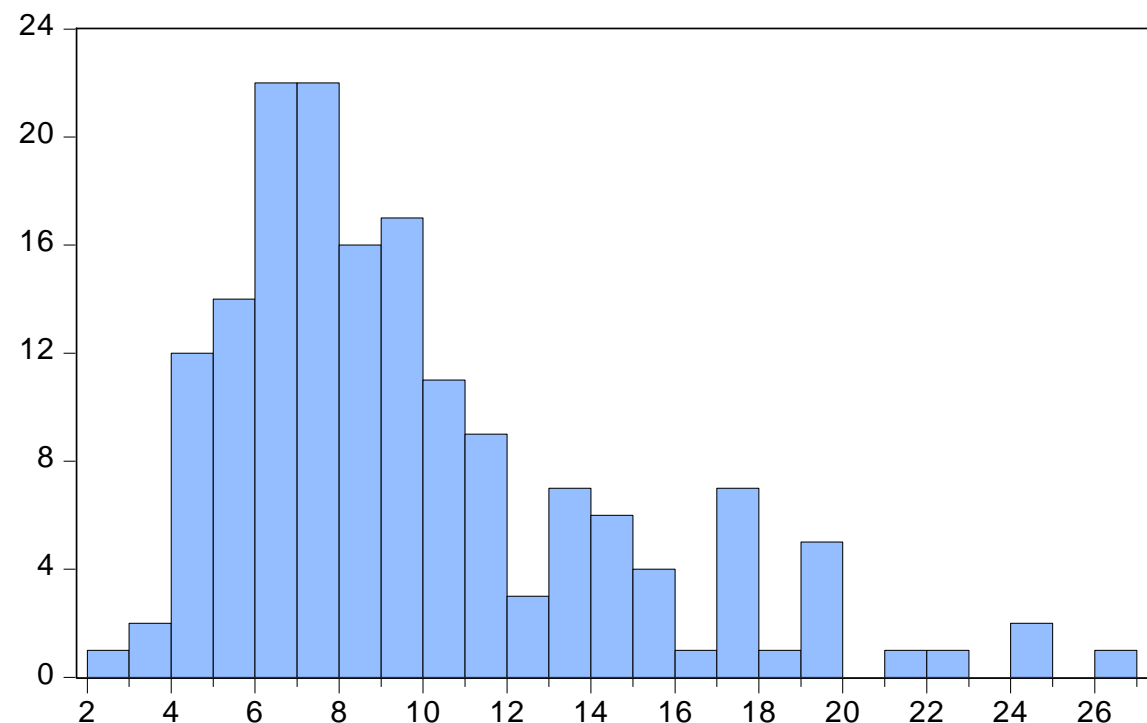

Series: UNEMPLOYMENT

Sample 20072017

Observations 165

Mean

9.809927

Median

8.500000

Maximum

26.09500

Minimum

2.890000

Std. Dev.

4.625650

Skewness

1.233230

Kurtosis

4.238293

Jarque-Bera

52.36545

Probability

0.000000

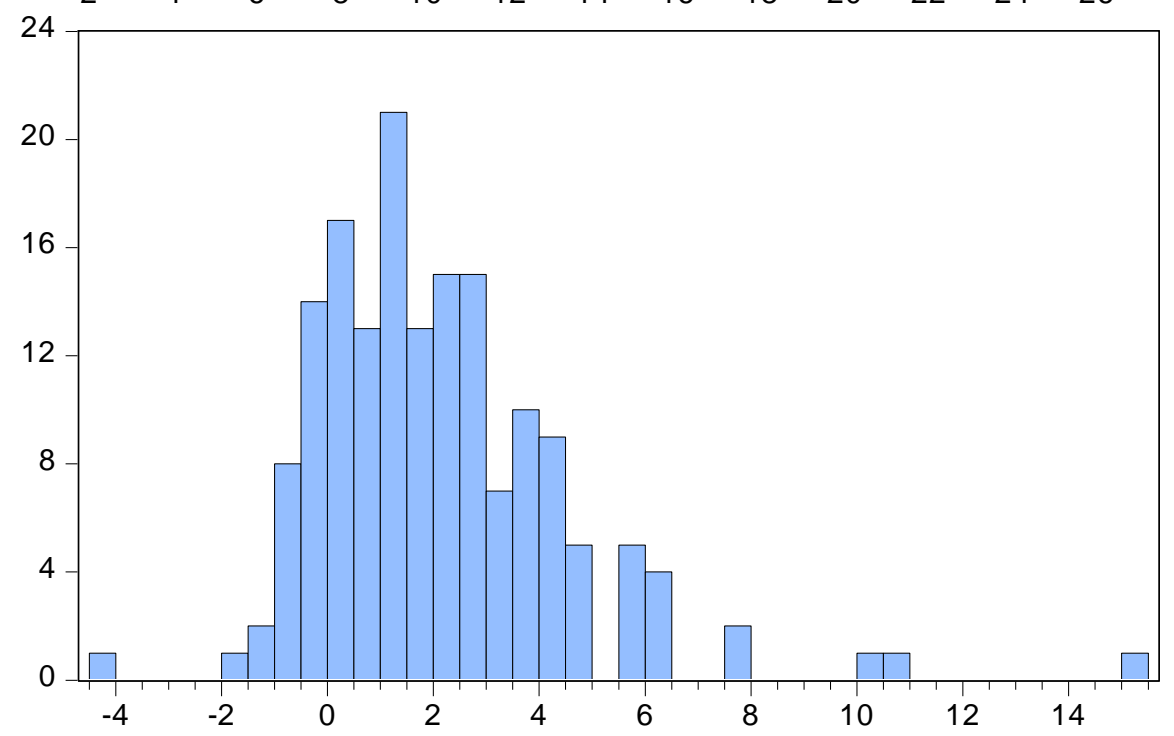

Series: INFLATION

Sample 20072017

Observations 165

Mean

2.112032

Median

1.733200

Maximum

15.40232

Minimum

$-4.478103$

Std. Dev.

2.406965

Skewness $\quad 1.636901$

Kurtosis

9.029743

Jarque-Bera $\quad 323.6447$

Probability $\quad 0.000000$ 